\title{
Local History Learning Based on The Struggle Of The Mobrig Troops In Yogyakarta To Increase Students' Historical Awareness
}

\author{
Arif Krisna Sudarmaji, Akhmad Arif Musadad, Hieronymus Purwanta \\ Universitas Sebelas Maret \\ krisnasays21@gmail.com
}

\section{Article History}

accepted 1/09/2020

approved 4/10/2020

published 1/12/2020

\begin{abstract}
An important problem that is often neglected in the study of Indonesian history today is the lack of discussion of the local historical context. History teachers are often fixated on the material presented in Iks and course textbooks. Like a lack of attention to historical events that have happened around. For this reason, it is necessary to introduce local historical material to increase students' historical awareness, such as material on the local history of the struggle of the Mobrig troops in Yogyakarta. The research methodology used to increase students' historical awareness is descriptive qualitative. This method is carried out by distributing a questionnaire containing questions about historical awareness. The findings obtained at SMK N 1 Pengasih Kulon Progo show that the historical awareness of students has increased, this can be seen after the researcher gave a questionnaire before and after providing material on the Fight for Mobrig Troops in Yogyakarta. Based on the results of the study, it can be concluded that by providing local history material to students at SMK N 1 Pengasih Kulon Progo it can increase students' historical awareness.
\end{abstract}

Keywords: Historical learning, the struggle of the mobrig troops, historical awareness

\begin{abstract}
Abstrak
Permasalahan penting yang sering kali terabaikan dalam pembelajaran sejarah Indonesia saat ini, berupa kurangnya pembahasan mengenai konteks sejarah lokal. Guru sejarah seringkali terpaku kepada materi yang disajikan dalam Iks dan buku paket mata pelajaran. Seperti kurangnya perhatikan peristiwa sejarah yang pernah terjadi di sekitar. Untuk itu diperlukan pengenalan materi sejarah lokal guna meningkatkan kesadaran sejarah siswa, seperti materi sejarah lokal perjuangan pasukan Mobrig di Yogyakarta. Metodologi penelitian yang digunakan untuk meningkatkan kesadaran sejarah siswa yaitu : kualitatif deskriptif . Metode ini dilakukan dengan menyebar angket yang berisikan pertanyaan mengenai kesadaran sejarah. Hasil temuan yang diperoleh pada SMK N 1 Pengasih Kulon Progo menunjukan hasil bahwa kesadaran sejarah siswa meningkat, hal ini dapat diketahui setelah peneliti memberikan angket sebelum dan sesudah memberikan materi Perjuangan Pasukan Mobrig di Yogyakarta. Berdasarkan hasil penelitian dapat disimpulkan bahwa dengan memberikan materi sejarah lokal pada siswa di SMK N 1 Pengasih Kulon Progo dapat meningkatkan kesadaran sejarah siswa.

Kata Kunci : Pembelajaran sejarah, perjuangan pasukan mobrig, kesadaran sejarah
\end{abstract}

Social, Humanities, and Education Studies (SHEs): Conference Series https://jurnal.uns.ac.id/shes
p-ISSN 2620-9284

e-ISSN 2620-9292 


\section{Pendahuluan}

Persoalan penting yang seringkali kurang mendapat perhatian dalam pembelajaran sejarah Indonesia yaitu, kurangnya membahas materi sejarah lokal. Guru sejarah seringkali terpaku pada bahan ajar yang tersaji dalam lks dan buku paket. Terkadang jarang memberikan materi sejarah, khususnya yang bersifat lokal. Akan tetapi tidak dipungkiri juga bahwa guru sejarah mengalami kendala dalam mengenalkan materi perisistiwa lokal dalam pembelajaran sejarah. Salah satu faktor yang biasanya dialami guru dalam megkaji materi sejarah lokal yaitu kurangnya refrensi, buku, maupun artikel yang membahas peristiwa sejarah lokal tersebut. Adapun mengapa peristiwa sejarah lokal itu perlu untuk diajarkan?

Menurut priyadi (2012: 6-7), bahwa sejarah lokal adalah suatu tempat atau ruang yang berkaitan dengan lokalitas tertentu dan disepakati oleh para pakar maupun penulis sejarah dengan argumen ilmiah. Contoh ruang tinggal suku bangsa maupun subsuku bangsa serta mempelajari sejarah dan budaya didaerah tinggalnya. Sejarah lokal merupakan sejarah dari suatu tempat yang biasanya ditentukan oleh perjanjian yang diajukan oleh penulis sejarah. Batas geografisnya dapat berbentuk tempat tinggal suatu bangsa, yang pada saat ini mungkin telah mencakup dua bahkan tiga daerah administratif tingkat dua atautungkat suku, dapat pula berbentuk sebuah kota maupun desa (Abdullah, 1990: 15). Sedangkan menurut Kartodirdjo (dalam Widja, 1991: 16), bahwa hal-hal yang terdapat dalam tingkat nasional baru dapat dipahami dengan baik apabila kita memahami perkembangan pada tingkatan lokal. Peristiwa sejarah yang berada pada scub yang lebih luas biasanya hanya memberi gambaran dari pola dan masalah yang bersifat umum. Sedangkan untuk situasi yang lebih kongkrit dan mendetail baru dapat dipahami melalui sejarah lokal tersebut. Dapat diartikan bahwa sejarah lokal merupakan suatu kegiatan yang berada didaerah tertentu yang meliputi aspek geografis, sumber sejarah. Berdasarkan hal tersebut materi sejarah lokal diharapkan dapat digunakan sebagai sarana pembelajaran sejarah.

Pentingnya pembelajaran sejarah lokal bagi siswa karena, pembelajaran sejarah lokal dapat menambah wawasan siswa mengenai perkembangan kehidupan masayarakat lokal pada masa lalu. Dengan mengkaitkan peristiwa yang pernah terjadi di sekitar siswa diharapkan siswa dapat lebih mengenal, mempelajari, dan menerapkan nilai-nilai peristiwa sejarah lokal (Eva Dina Chairunisa, 2017: 61). Sementara menurut Widja (1989: 113) dalam Novitasari 2017: 56) fungsi lain dalam pengajaran sejarah lokal yaitu murid akan memperoleh berbagai jenis sumber belajar seperti mepelajari pengalaman dari sebuah peristiwa. Sedangkan menurut Doch (dalam Subagyo, 2010: 253), bahwa pengaplikasian sejarah lokal dapat dibagi kedalam tiga bentuk. Pertama, mengambil contoh dari kajian sejarah lokal untuk memberi gambaran rill dari uraian sejarah nasional maupun dunia yang diajarkan, kedua, adalah melalui bentuk kegiatan penjelajahan lingkungan, dan ketiga yakni, melalui studi kasus mendalam mengenai berbagai aspek kesejarahn di lingkungan murid. Dengan demikian dapat diartikan bahwa pembelajaran sejarah memang penting diterapkan pada siswa sehingga mereka sadar akan sejarah yang berada di lokasi mereka dan tidak selalu belajar sejarah yang jauh dari tempat tinggal mereka.

Menurut Khubaib (2017: 75) Orang yang tidak memahami sejarahnya tidak akan mampu menjadi manusia yang paripurna. Pemahaman sejarah yang benar dapat menimbulkan kesadaran dalam diri setiap insan bahwa segala sesuatu yang terjadi pada saat ini merupakan hasil dari produk masa lalu dan apa yang terjadi di masa depan ditentukan oleh apa yang dilakukan saat ini. Kesadaran sejarah haruslah diupayakan memalui proses penyadaran sejarah. Adapun hal tersebut dapat dilakukan secara bertahap melalui pembinaan baik formal maupun informal. Membangun dan menumbuhkan kesadaran sejarah diharapkan mampu mendorong geerasi muda dapat memahami sejarah yang berada disekitarnya. 
Pembelajaran sejarah yang ideal untuk menerapkan materi sejarah lokal yaitu terdapat pada KD 3.10. Dalam KD tersebut menjelaskan tentang "menganalisis strategi dan bentuk perjuangan bangsa Indonesia dalam upaya mempertahankan kemerdekaan dari ancaman sekutu dan Belanda". Pada KD tersebut, peneliti ingin menerapkan materi pembelajaran dengan tema sejarah lokal yaitu Perjuangan Pasukan Mobrig di Yogyakarta. Materi ini menggambarkan peristiwa sejarah terbentuknya Mobrig, serta perannya dalam perang kemerdekaan di Yogyakarta. Pasukan Mobrig yang berada di Yogyakarta tergabung dalam kesatuan organis MBB-DKN. Lokasi peristiwa pertempuran antara pasukan Mobrig MBB-DKN pimpinan Komisaris Polisi R.M. Broto Mardoekoesomo. Adapun untuk wilayah Yogyakarta terbagi kedalam dua kompi pasukan yakni pasukan kompi I dan kompi IV . Ketua lapangan kompi I dipimpin oleh IP Rachmat Setiawirja yang bermarkas di Ganjuran. Sedangkan pasukan kompi IV dipimpin oleh IP II Djohan Soeparno dengan pasukannya yang mayoritas merupakan pelajar polisi dan bermarkas di Sekolah Polisi Negara (SPN) Ambarukmo. Dalam Perang Kemerdekaan II, Pasukan Mobrig berperan membantu menghambat pergerakan pasukan Belanda mulai daerah Janti, Gendeng, Timoho, Lempuyangan, Pakualaman, Gondomanan, dan turut serta dalam perang Gerilya di sekitar daerah Banyakan, Kotagede, ganjuran, dan Pleret. Pasukan Mobrig juga turut serta dalam Serangan Umum 1 Maret 1949.

Berdasarkan uraian di atas, peneliti tertarik untuk menggunakan materi sejarah lokal perjuangan pasukan Mobrig dalam pembelajaran sejarah menggunakan KD 3.10. Dengan harapan dapat meningkatkan kesadaran sejarah siswa mengenai peristiwa sejarah yang terjadi di sekitar siswa yang tidak terdapat pada lks dan buku paket.

\section{METODOLOGI}

Penelitian ini menggunakan metode kualitatif deskriptif. Penelitian kualitatif digunakan untuk memahami, mendekati, menggali serta mengungkap suatu fenomena tertentu dari responden penelitiannya. Menurut Creswell (2008), penelitian kualitatif merupakan suatu pendekatan atau penelusuran untuk mengeksplorasi dan memahami suatu gejala sentral. Penelitian kualitatif mempunyai sifat induktif, peneliti membiarkan permasalahan muncul dari data untuk interprestasi. Data dihimpun melaluipengamatan seksama, mencakup deskripsi dalam konteks yang mendetail disertai dengan catatan mendalam serta analisis dokumen dan catatan (Sukmadinata, 2007: 60). Sedangkan penelitian deskriptif digunakan untuk menggambarkan fenomena-fenomena yang ada, dan sedang ataupun yang telah terjadi. Suharmisi Arikunto (2010: 3), berpendapat bahwa penelitian deskriptif merupakan penelitan yang mempunyai tujuan untuk menggambarkan atau memaparkan suatu hal seperti keadaan, kondisi, situasi, peristiwa, kegiatan dan lain-lain. Menurut Furchan (2004: 54), penelitian deskriptif mempunyai karakteristik yakni: pertama, cenderung menggambarkan suatu fenomena yang apa adanya dengan cara menelaah secara teratur dan ketat. Mengutamakan objektivitas dan dilakukan secara cermat. Kedua, tidak perlakuan yang diberikan atau uji $h$.

Teknik penelitian yang digunakan untuk meningkatkan kesadaran sejarah siswa setelah mempelajari materi Perjuangan Pasukan Mobrig di Yogyakarta. Dengan menggunakan kuisioner, adapun kisioner yang dipergunakan untuk mengukur kesadaran sejarah yakni: pertama, menghayati makna dan hakekat sejarah, kedua, mengenal diri sendiri dan bangsanya, ketiga, membudayakan sejarah bagi pebinaan budaya bangsa, keempat, menjaga peninggalan sejarah bangsa.

\section{HASIL DAN PEMBAHASAN}

Berdasarkan hasil penelitian yang telah dilakukan pada siswa di SMK N1 Pengasih Kulon Progo Yogyakarta dengan jumlah responden sebanyak 32 siswa. 
Penyebaran angket tersebut diterapkan pada kelas X TSM. Angket yang diberikan bertujuan untuk mengetahui sejauh mana siswa mengerti materi pembelajaran sejarah lokal dengan tema perjuangan pasukan mobrig di Yogyakarta. Data yang diperoleh kemudian dianalisis untuk mengetahui keefektifan materi pembelajaran sejarah lokal perjuangan pasukan mobrig dalam perang kemerdekaan di Yogyakarta. Adapun hasil dari penelitian tersebut menghasilkan data sebagai berikut:

Hasil pre-test yang didistribukan menggunakan diagram Pie sebagai berikut:

Gambar 1. Diagram Pei Pre-Test

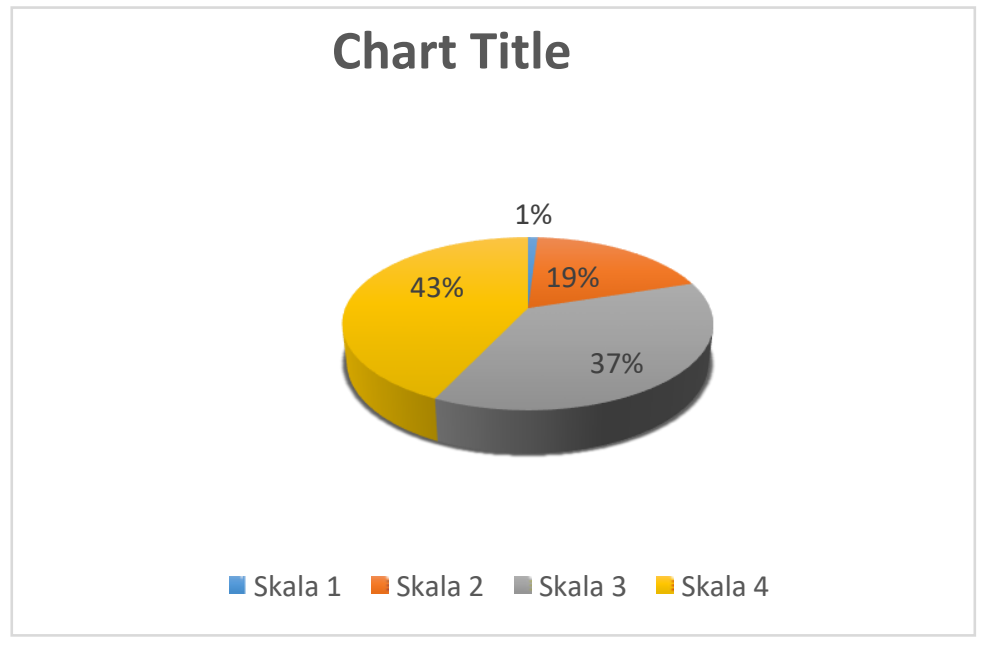

Grafik ini menggambarkan hasil kuisioner atau angket sebelum diberikan materi Perjuangan Pasukan Mobrig di Yogyakarta. Kuisioner tersebut terdiri dari lima pertanyaan. Pertanyaan yang dipaparkan menggunakan empat indikator yaitu, 1. Menghayati makna dan hakekat sejarah, 2. Mengenal diri dan bangsanya, 3. Menbudayakan sejarah bagi pembinaan budaya bangsa, 4. Menjaga peninggalan sejarah bangsa.

\section{Gambar 2. Diagram Pei Post-Test}

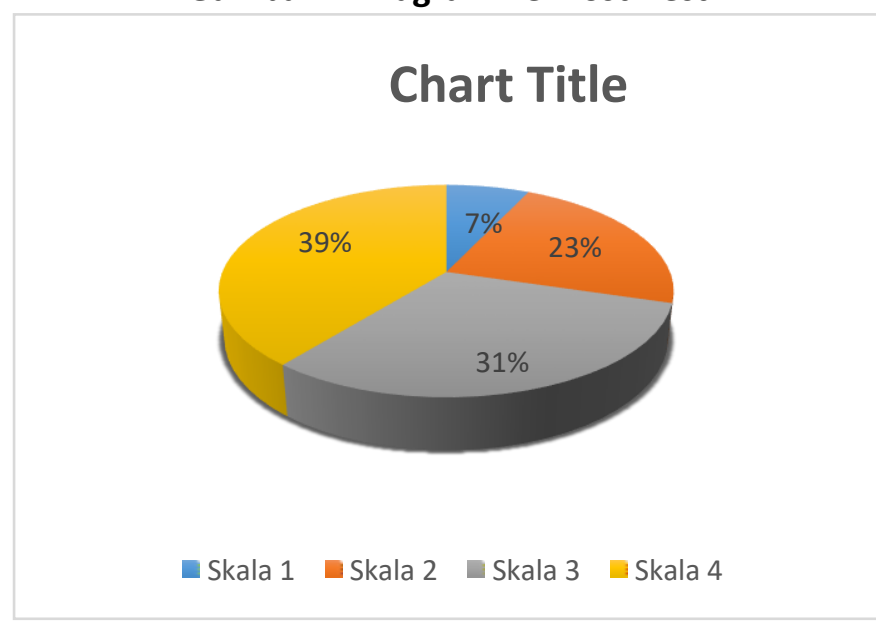

Grafik ini menjelaskan peningkatan setelah diperlakukan pembelajaran sejarah lokal dengan materi perjuangan pasukan mobrig di Yogyakarta. Penelitian tersebut menggunakan empat indikator yakni, 1. Menghayati makna dan hakekat sejarah, 2. Mengenal diri dan bangsanya, 3. Membudayakan sejarah bagi pembinaan budaya 
bangsa, 4. Menjaga peninggalan sejarah bangsa. Adapun hasil yang diperoleh sebagai berikut:

\section{PEMBAHASAN}

Berdasarkan hasil penelitian yang telah dilakukan dengan menyebar kuisioner kesadaran sejarah pada siswa SMK N 1 Pengasih Kabupaten Kulon Progo dengan satu kelas yang terdiri dari 32 siswa. Penyebaran angket tersebut dilakukan kepada kelas $X$. Kuisioner yang diberikan bertujuan untuk mengetahui kesadaran sejarah siswa dalam mempelajari bahan ajar Perjuangan Pasukan Mobrig di Yogyakarta. Data yang didapat kemudian dianalisis guna mengetahui kesadaran sejarah siswa menggunakan jenis kuisioner dengan 20 pertanyaan. Adapun pembahasan yang akan dilakukan adalah sebagai berikut:

Berdasarkan hasil penelitian yang telah dilakukan melalui materi pembelajaran perjuangan pasukan mobrig pada perang kemerdekaan di Yogyakarta, didapati pada hasil pre test bahwa: 1. Menghayati makna dan hakekat sejarah, Siswa kelas X TSM di SMK N 1 Pengasih Kulon Progo. Hasil yang didapat setelah melakukan penyebaran angket memperoleh presentase yakni: Skala 1 yaitu $7 \%$, Skala 2 yaitu 23\%, Skala 3 yaitu 31\%, Skala 4 yaitu, 39\%. Sementara hasila dari post tes setelah diberikan materi perjuangan pasukan mobrig pada perang kemerdekaan di Yogyakarta, memperoleh presentase: skala 1 yaitu, $1 \%$, skala 2 yaitu, 19\%, skala 3 yaitu, $43 \%$. Dapat diartikan bahwa penilaian kesadaran searah siswa di SMK N 1 Pengasih Kulon Progo telah menunjukan peningkatan. Hal tersebut dapat terlihat dari presentase skala pada kuisioner menunjukan adanya peningkatan.

\section{KESIMPULAN}

Berdasarkan hasil dan pembahasan yang telah dilakukan dapat disimpulkan bahwa peningkatan kesadaran sejarah siswa telah meningkat. Hali ini dapat diketahui setelah peneliti mengukur menggunakan kuisioner dengan keempat indikator kesadaran sejarah meliputi: : pertama, menghayati makna dan hakekat sejarah, kedua, mengenal diri sendiri dan bangsanya, ketiga, membudayakan sejarah bagi pebinaan budaya bangsa, keempat, menjaga peninggalan sejarah bangsa.Adapun hasil yang dapat dilihat dengan menggunakan diagram pie.

\section{DAFTAR PUSTAKA}

Abdullah Taufiq. (1990). Sejarah Lokal di Indonesia. Yogyakarta : Gadjah Mada University Press.

Arikunto Suharmisi. (2010). Prosedur Penelitian Suatu Pendekatan Praktik. Jakarta: Rineka Cipta.

Cresswell. (2008). Research Design. Yogyakarta : Pustaka Belajar.

Daliman. (2015). Pengantar Filsafat Sejarah. Yogyakarta : Ombak.

Furcan A. (2004). Penelitian dalam Pendidikan. Yogyakarta : Pustaka Pelajar Ofsett.

Gagne. RM, Briggs. LJ, \& Wagner W.W. (1992). Principal of Instructional Design $\left(4^{\text {th }}\right)$.Orlando: Holt. Rinehart. and Winston.

Na'im, M, dkk. (2017). Upaya meningkatkan Aktivitas dan Hasil Belajar Penerapan Melalui Model Pembelajaran Kooperatif Tipe Group Investigation Pada Mata Pelajaran Sejarah. Jurnal Pendidikan Humaniora No. 55 Vol 1.

Novitasari Ratnaningtyas Ayu. Hanif Muhammad. (2017). Tari Kecetan Dalam tradisi Keduk Beji Desa Tawun Kecamatan Kasreman Kabupaten Ngawi (Manka Simbolis dan Sumber Pembelajaran Sejarah Lokal). Agastya Vol. 7. No. 1.

Priyadi Sugeng. (2012). Sejarah Lokal: Konsep, Metode, dan Tananganya. Yogyakarta: Ombak. 
Putro, Herry Porda Nugroho. (2006). Model Pembelajaran Sejarah untuk Meningkatkan Kesadaran Sejarah melalui Pendekatan Inkuiri (Studi Pembelajran pada Siswa Sekolah Menengah Pertama Negeri di Kota Banjarmasin- Kalimantan Selatan). Tesis. UPI. http :// reprository. upi.edu/7686/ (diakses pada 2409 2020).

Subagyo.(2003). Membangun Kesadaran Sejarah. Widya karya. Semarang. Sukmadinata, Nana Syaodih. (2007). Metode Penelitian Pendidikan. Bandung :Remaja Rosdakarya.

Triyanto. (2009). Mendesain Model pembelajaran Inovatif- Progresif. Jakarta : Kencana.

Wasino. (2009). Pokok- Pokok Pikiran untuk Penulisan Sejarah Lokal. Makalah Koordinasi dan Curah Pendapat Penguatan Sejarah Lokal untuk meningkatkan Wawasan Kebangsaan Deputi Menko Kesra Bidang Koordinasi Kebudayaan ,Pariwisata, Pemuda, dan Olah Raga, Semarang. Patra Jasa.

Widja. I. Gde. (1989). Dasar- Dasar Pengembangan Strategi Serta Metode Pengajaran Sejarah. Jakarta : Depdikbud.

Widja. I. Gde. (1991). Sejarah Lokal: Suatu perspektif Dalam Pengajaran Sejarah. Bandung: Angkasa. 